\title{
Örtüaltı sebze üretiminde üreticilerin tohum tercihini etkileyen faktörlerin belirlenmesi: Antalya ili örneği
}

Determination of factors affecting of producers' seed preferences in greenhouse vegetable growing: The case of Antalya province

\author{
Teoman HIZAL ${ }^{1 \mathscr{A}}$ (D), Bahri KARLI ${ }^{1}$ iD \\ ${ }^{1}$ Isparta University of Applied Sciences, Faculty of Agriculture, Agriculture Economics, Isparta,Turkey.
}

MAKALE BILGISI / ARTICLE INFO

Makale tarihçesi / Article history:

DOI: $10.37908 /$ mkutbd.690286

Geliş tarihi /Received:09.05.2020

Kabul tarihi/Accepted:09.10.2020

\section{Keywords:}

Seed, cultivar preference, greenhouse vegetable growing, producer preferences, Antalya.

\footnotetext{
Corresponding author: Teoman Hıza

$\bowtie$ : teomanhizal07@gmail.com
}

\section{ÖZET / A B STR A C T}

\begin{abstract}
Aims: In this study, it was aimed to determine the seed and seedling preferences of greenhouse vegetable producers and to determine the factors affecting seed or seedling preferences in Serik, Aksu, Kumluca and Gazipaşa districts of Antalya province.

Methods and Results: The main material of the research was consisted of the data collected by face to face the survey with 96 greenhouse farmers in Serik, Aksu, Kumluca and Gazipaşa districts of Antalya. The greenhouse farms in this study were divided into 3 groups by considering the acreages as $0-3,3.1-7.5$, and 7.6 decare. According to the results of the research, it was found that the average greenhouse area was 7.36 decares, the average age of producers was 41.63 years and the experience of growing vegetables was 19.69 years. It was determined that the most common vegetables produced in the farms were tomatoes $(54.16 \%)$, pepper $(34.38 \%)$, cucumber $(30.21 \%)$ and other vegetables $(15.63 \%)$. The most important reasons for preferring greenhouse vegetable growing were found as traditional production habits $(78.13 \%)$ and suitability for land and climatic conditions (70.83\%). $85.45 \%$ of the producers stated that they needed information on farming whereas $14.58 \%$ of the producers did not. It was found that $79.17 \%$ of the producers received information needed from agricultural engineers / technicians and $70.83 \%$ from other farmers. The most problems of the farmers was high input prices with $96.89 \%$ share and followed by diseases and pests with $58.33 \%$ share. In addition, low prices of products with $87.50 \%$ share was the leading marketing problem of the producers, followed by instable nature of market with $62.50 \%$.

Conclusions: The greenhouse vegetable producers should have a priority to decide on type of the vegetable to plant it and then the varieties of it. It was founded that $90.65 \%$ of the producers surveyed decides himself on the type of vegetables, followed by producers asking for other farmers (33.33\%) and seedlings producers (20.83\%). In addition, majority of the producers $(75.00 \%)$ were found to be satisfied with the vegetable cultivar they grow. Besides, $17.71 \%$ of the producers were not satisfied and only $7.29 \%$ were very satisfied.

Significance and Impact of the Study: Determination of the factors affecting seed preferences of greenhouse vegetable producers in Antalya province and determination of the relations between these factors.
\end{abstract}




\section{Giriş}

Günümüzde tarımsal üretimde en önemli yetiştiricilik yöntemlerinden biri olan örtüaltı yetiştiriciliği (seracılık) her geçen gün alan ve yapılan üretim miktarları ile artış göstermektedir. Örtüaltı yetiştiriciliği, birim alana düşen işgücü ve sermaye açısından tarımın en yoğun uygulama alanını oluşturmaktadır. Örtüaltı yetiştiriciliği, tarımsal üretim sektörleri arasında istihdamın en fazla olduğu sektörlerden başında yer almaktadır. Yaklaşık 50 yılı aşkın bir geçmişi olan Türkiye'deki seracılığın çok hızlı bir gelişme kaydederek, gerek üretim gerekse ihracat açısından önemli bir sektör haline geldiği görülmektedir (Anonim, 2014). Örtüaltı sebze yetiştiriciliğinde, ihracatın ve sezon dışı üretimin öne çıkması; doğru tohum kullanımının önemini artırmaktadır. Nitekim, hibrit çeşit ıslahının ve değişken amaçlı çeşitlerin en fazla olduğu sektör ise sebze tohumculuk sektörüdür. Türkiye'nin tarım ihracat potansiyelinin gittikçe artması, sebze tohumculuğunu hızlı bir ivme ile geliştirmekte olduğu söylense de, burada girdilerde kullanılan tohumların ne kadarının ithal edildiği konusu önemlidir (Demir vd., 2010).

Kaliteli tohum kullanımını; çiftçilerin teknik bilgi düzeyi, sahip olduğu mali koşullar ve tohum fiyatlarını etkilemektedir. Çiftçiler, girdi olarak kullandığı tohum fiyatları ile ürettiği ürünün fiyatı arasında bir bağlantı kurmaktadır. Tohum fiyatındaki artışın ürün fiyatlarındaki artışlardan daha fazla olduğu dönemlerde, çiftçiler olumsuz olarak etkilenmekte ve sertifikalı tohumluğa olan talepleri azalmaktadır. Tohum fiyatlarındaki değişiklikler, sadece sertifikalı tohum talebini değil, aynı zamanda tohum ve tohumluk üreticilerinin tohumluk üretimi yapma kararlarını da etkilemektedir. Bu öneminden dolayı Türkiye'de ve dünyada tohum sektörünün genel değerlendirilmesinin yapılması, tohum üretimi ve ticaretinin irdelenmesi, tohum yetiştiriciliğinin analiz edilmesi ve sözleşmeli yetiştiricilik modeli ile tohum üretimi ilişkisinin ortaya konulması amaçlarıyla farklı yerlerde ve zamanlarda araştırmalar yapılmıştır. Yapılan bu araştırmaların çoğu ikincil verilere dayanmaktadır. İşletme düzeyinde birincil verilere dayalı olarak gerçekleştirilen araştırma sayısı oldukça sınırlıdır.

Tohum kullanımı, tohum üretim durumu, tohum pazarlama yapısı, tohum dağıtımı ve ticaretine yönelik araştırmalar (Balcı, 1993; Usal, 1996; Akdoğan, 2003; Demirtaş ve Keleş, 2005; Yağdı vd., 2010; Gül vd., 2015) mevcut olup, konunun ekonomik yönüyle ilgili olarak çalışmalar yetersizdir. Örtüaltı sebzeciliğinin teknik yönleri hakkında Demir vd., (2010); Balkaya vd., (2015); karlılık konusunda Emekli vd., (2010) ve Başbuğ ve Gül (2016); pazarlamayla ilgili olarak Usal (1996), Gerger ve Karlı (1999), Fert (2004) ve Demirtaş ve Keleş (2005); tohum satın alma davranışları ile ilgili Kang vd., (2015) ve Güngör vd., (2016), fiyatlarla ilgili olarak Hazneci ve Ceylan (2016), dış ticaretle ilgili olarak Sav ve Sayın (2016) ve politikalarla ilgili olarak Yılmaz (2014)'ın çalışmaları sayılabilir. Bu çalışmada incelenecek olan örtüaltı sebzecilikte tohum seçimine etki eden faktörlerin belirlenmesi konusu ise bu bölge ölçeğinde çalışılmamış bir konudur. Günümüzde, özellikle örtüaltı sebze üreticileri üretim yapacağı ürünü artık büyük oranda tohum olarak satın almamaktadır. Bu konuda uzmanlaşmış fide şirketlerine yetiştireceği çeşidi sipariş vererek, bu fideyi kullanmak suretiyle ihtiyaçlarını karşılamaktadırlar. Bu nedenle, bu çalışmada tohum tercihi kavramı, satın aldığı tohum değil, yetiştireceği tohum çeşidini ifade etmektedir.

Antalya ilinde sebze üretim faaliyetinde bulunan üreticilerin tohum tercihlerini etkileyen faktörlerinin belirlenmesini hedefleyen bu çalışmanın başlıca amaçları aşă̆ıdaki şekilde özetlenebilir;

- Antalya ilinde sebze üreticilerinin kullandıkları tohum tercihlerini belirlemek,

- Antalya ilinde sebze üreticilerinin tohum tercihlerini etkileyen faktörleri analiz etmek,

- Elde edilen veriler ışığında bu konularda uygulanacak politikalara katkıda bulunmaktır.

Dünyada tarımsal faaliyet yapılabilecek alanların sınırlı olması ve artan nüfusun besin ihtiyaçlarının karşılanabilmesi için birim alandan daha fazla verim alınması önem arz etmektedir. Verim artışının gerçekleştirilebilmesi ise genotip ve yetiştirme tekniklerinin iyileştirilmesi ile mümkün olabilecektir. Dolayısıyla, yetiştirme tekniklerinin iyileştirilmesi ve bölgeye uygun nitelikli tohum çeşidinin kullanılması ile verim artışında başarı sağlanabilecektir. Kaliteli tohumluk kullanımı ile ürün verimini; kendine döllenen türlerde \%20-30, yabancı döllenen türlerde 2-3 kat ve hatta hibrit tohumluklarda 8-10 kat artırmak mümkün olmaktadır (Akdoğan, 2003). Dünya tohumculuk endüstrisinin yıllık toplam cirosunun 50 milyar \$ olduğu düşünülmektedir. Ülkelerin 2011 yılı tohum pazarı büyüklükleri Şekil 1'de görülmektedir. Buna göre, ABD ve Çin dünya pazarında en büyük paya sahip ülkelerdir. Türkiye ise 750 milyon dolar ile dünya pazarında dokuzuncu büyük ülke durumundadır(Worldseed, 2016). 


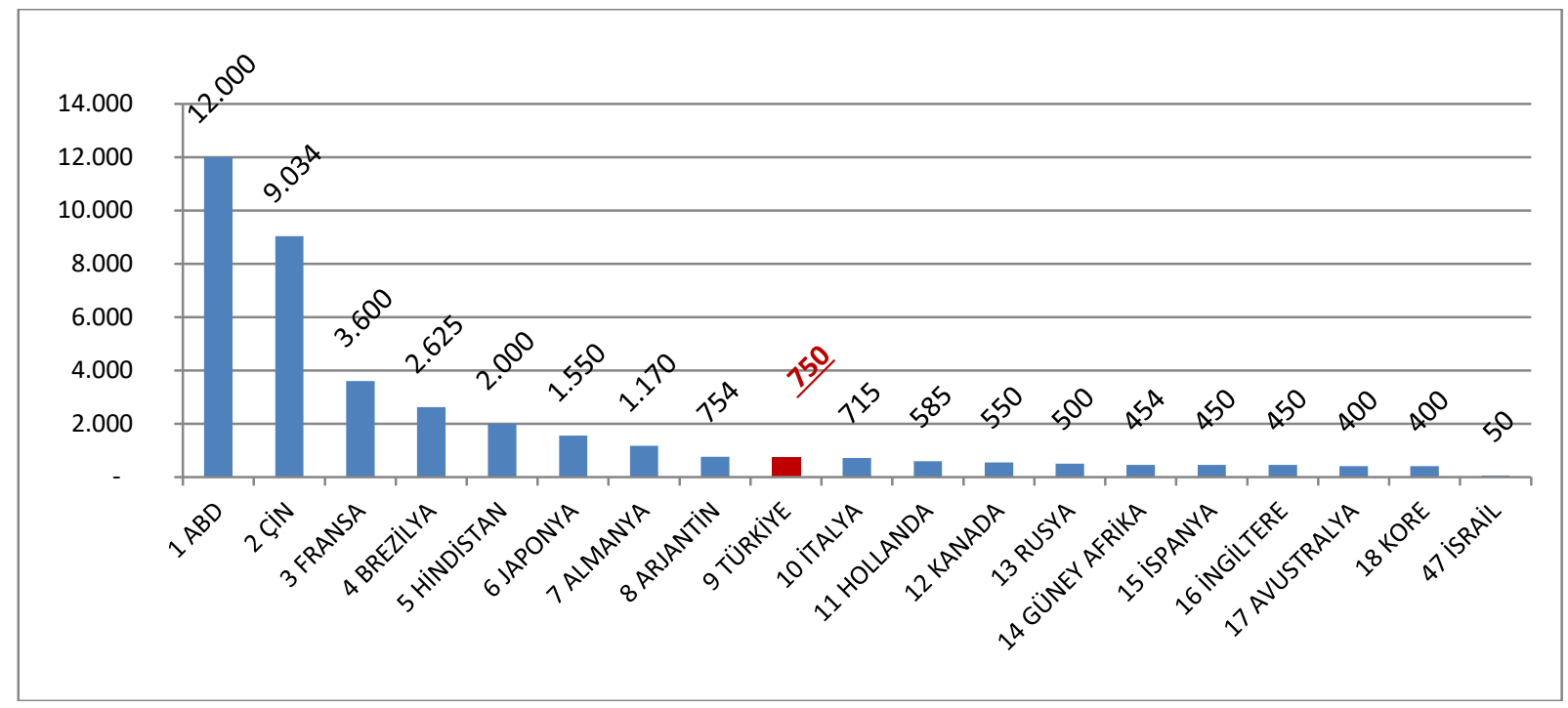

Şekil 1. Ülkelerin 2011 yılı tohum pazarı (milyon \$) (Worldseed, 2016)

Figure 1. Seed markets of countries in 2011 (million \$) (Worldseed, 2016)

Türkiye'de tohumculuk sektöründe sebze tohumculuğunun önemi büyüktür ve gittikçe önemini artırmaktadır. 2011 yılı itibariyle sebze tohumculuğu 300 milyon dolar ile toplam tohumculuk pazarından $\% 55$ pay almaktadır (TSÜAB, 2016). Türkiye'de sebze sektörünün temelini oluşturan tohum sektörü son 25 yılda büyük gelişme göstermiş, bir yandan yurt içi tohumluk üretimini artırmak, diğer yandan da yerli tohumculuğun geliştirilmesi konusunda özel sektör önemli çalışmalar yapmaktadır.

Domates, ürünler açısından sebze tohum pazarında en büyük payı alan üründür ve toplamdaki payı $\% 44$ civarındadır (TSÜAB, 2016). Domatesi, biber, hıyar ve soğan takip etmektedir. Türkiye tohum pazarının yaklaşık yarısını sebze tohumları ve sebze tohumlarının da yine yarısına yakınını domates tohumu oluşturmaktadır. Sebze tohumlarının üretiminde, özellikle kış aylarında Antalya ili ön sırada yer almaktadır. Türkiye'de örtüaltı sebze üretiminde başlıca ürünlerin üretim miktarındaki gelişmelerin son 5 yıldaki gelişimi Çizelge 1'de verilmiştir. Buna göre, örtüaltı sebze üretiminde domates, hıyar ve biber toplam ekim alanı içinde önemli bir paya sahip olduğu görülmektedir. Bu üç ürünün üretim miktarlarının da son 5 yılda az miktarda bir artış görülmektedir.

Araştırma alanı olarak seçilen Antalya ili, örtüaltı sebze üretiminde hem ekim alanı hem üretim miktarı açısından en önemli illerin başında gelmektedir. 2014 yılında Türkiye örtüaltı sebze üretiminde ekim alanı açısından 264.170 da ile toplam içerisinde $\% 42.87$ pay almaktadır. Bu gösterge örtüaltı sebze üretiminde Antalya ilinin öneminin açık bir göstergesidir.

Çizelge 1. Örtüaltı sebze ekim alanlarının yıllara göre iller düzeyindeki payları (TÜiK, 2019)

Table 1. The shares of greenhouse vegetable areas by years at the provincial level (TURKSTAT, 2019)

\begin{tabular}{lrrrrrr} 
iller & \multicolumn{2}{c}{ Yıllar itibariyle iller düzeyinde örtüaltı sebze yetiştirme alanları (dekar) } & \multicolumn{1}{c}{$\begin{array}{c}\text { Pay } \\
\text { (2018, \%) }\end{array}$} \\
\hline Antalya & $\mathbf{2 0 1 4}$ & $\mathbf{2 0 1 5}$ & $\mathbf{2 0 1 6}$ & $\mathbf{2 0 1 7}$ & $\mathbf{2 0 1 8}$ & \\
Adana & 264.170 & 277.645 & 289.275 & 305.310 & $\mathbf{3 0 7 . 9 8 1}$ & $\mathbf{4 1 . 5 9}$ \\
Mersin & 94.035 & 95.836 & 106.889 & 134.586 & 148.919 & 20.11 \\
Muğla & 113.888 & 113.871 & 113.585 & 132.160 & 127.153 & 17.17 \\
İzmir & 44.017 & 47.090 & 48.371 & 48.064 & 48.402 & 6.54 \\
\hline G. Toplam & 11.553 & 11.933 & 13.277 & 13.279 & 13.278 & 1.79 \\
\hline
\end{tabular}

Örtüaltı yetiştiriciliğinin en önemli merkezlerinden biri olan Antalya ilinde örtüaltı yetiştiriciliği bazı ilçelerde çok az, bazılarında ise oldukça yüksek oranda yaygın olarak üretim yapılmaktadır. Toplam 19 ilçenin ekim alanları incelendiğinde, Antalya ilinde, örtüaltı sebze alanlarının ekim alanı açısından değerlendirildiğinde, \%10'un 
üzerinde ekilen alanlara bakıldığında 4 ilçenin (Kumluca, Serik, Aksu ve Gazipaşa) dikkat çekici olarak başı çektiği görülmektedirler. Bu dört ilçe, Antalya ilinin tüm ilçeleri ile değerlendirildiğinde, toplam alanların yarısını (\%50.45) oluşturmaktadır (Çizelge 2).

Çizelge 2. Antalya ilinde örtüaltı sebze ekim alanlarının yıllara göre değişiminin ilçeler düzeyinde payları (TÜiK, 2019) Table 2. District-level share of greenhouse vegetable areas province by years in Antalya (TURKSTAT, 2019)

\begin{tabular}{|c|c|c|c|c|c|c|}
\hline \multirow{2}{*}{ îlçeler } & \multicolumn{5}{|c|}{ Yıllar itibariyle ilçeler düzeyinde örtüaltı sebze yetiştirme alanları (dekar) } & \multirow{2}{*}{$\begin{array}{c}\text { Toplamdaki } \\
\text { paylar } \\
(2018, \%)\end{array}$} \\
\hline & 2014 & 2015 & 2016 & 2017 & 2018 & \\
\hline Kumluca & 37.200 & 42.580 & 42.550 & 42.550 & 42.501 & 15.00 \\
\hline Serik & 35.986 & 35.731 & 36.181 & 36.881 & 37.156 & 13.12 \\
\hline Aksu & 31.898 & 31.898 & 31.898 & 31.223 & 31.863 & 11.25 \\
\hline Gazipaşa & 26.765 & 28.000 & 28.400 & 30.200 & 31.400 & 11.08 \\
\hline G. Toplam & 248.253 & 258.552 & 268.340 & 278.063 & 283.283 & 100.00 \\
\hline
\end{tabular}

Araştırmada, Antalya ilinde sebze ekim alanı, üretimi ve sebze yetiştiren çiftçi sayısı yönlerinden önemli yeri olan (\%50.45) Kumluca, Serik, Aksu ve Gazipaşa ilçelerinde tarım işletmelerinde sebze tohumluklarını kullanma düzeyleri ortaya konmuş, tohum çeşidi ile ilgili olduğu düşünülen faktörlerin kendi arasındaki ilişkileri tespit edilmiş ve üreticilerin bu konuyla ilgili sorunları, istekleri belirlenerek çözüm önerileri geliştirilmiştir.

\section{MATERYAL ve YÖNTEM}

\section{Materyal}

Çalışmanın ana materyalini, Antalya ilinin merkez ve ilçelerinde örtüaltında sebze tarımıyla uğraşan 96 üreticiden yüz yüze anket yöntemiyle elde edilmiş orijinal nitelikli veriler oluşturmuştur. Bunun yanında araştırmanın ikincil verileri olarak konu ile ilgili yapılmış araştırma ve inceleme sonuçları, Birleşmiş Milletler Gıda ve Tarım Organizasyonu (FAO), Türkiye İstatistik Kurumu (TÜIK), Tarım ve Orman Bakanlığı (TOB), Tohum Sanayicileri Üreticileri Alt Birliği (TSÜAB), Uluslararası Tohum Federasyonu (ISF) tarafından yayınlanmış kaynaklar ve istatistiki kayıtlardan yararlanılmıştır.

\section{Yöntem}

Örnek sayısını belirlemek amacıyla T.C. Tarım ve Orman Bakanlığı Antalya Tarım ilı Müdürlüğü'nden, 10.12.2016 tarihi itibariyle Antalya ilindeki Örtüaltı Çiftçi Kayıt (ÖKS) sistemine kayıtlı üretici sayısının 20.663 olduğu bilgisi alınmıştır (TOBAi, 2016). Buna göre, anket uygulanan örnek sayısının belirlenmesinde "Sonlu Anakitle" formülünden yararlanılmıştır. Örnek sayısı, \%95 güven aralığında ve $\% 10$ hata payında 96 olarak belirlenmiştir.

$n=\frac{N p(1-p)}{(N-1) \sigma^{2}+P(1-P)}$
Formülde:

$\mathrm{n}=$ Örnek Hacmi

$\mathrm{N}=$ Anakitledeki toplam birim sayısı

$\sigma^{2}=$ Anakitle varyansı

$N$ büyüklügündeki sonlu bir anakitle için, belli bir özelliği taşıyanların bilinen veya tahmin edilen oranına $(p)$ göre örnekleme yapılmak isteniyorsa, örnek hacmi formülü yukarıdaki gibi olacaktır. Burada $p$, üzerinde çalışılan özelliğin anakitledeki oranı veya rastlanma olasılığıdır. $p$, daha önceki araştırma veya deneyimlerden elde edilebileceği gibi, sezgisel olarak da tahmin edilebilir. Maksimum örnek hacmine ulaşabilmek için $p=0.5$ alınmış. p'nin, 0.5 'ten daha az ve daha yüksek değerleri, örnek hacmini düşürmektedir. $O$ nedenle $p^{\prime}$ nin bilinmediği durumlarda maksimum örnek hacmiyle çalışmak olası hatayı azaltacağından $p=0.5$ alınması önerilebilir. $\sigma_{p x}^{2}$ ise oranın varyansıdır (Miran, 2010). Araştırma Antalya ili örtüaltı sebzeciliğin en çok yapıldığı ve ili temsil kabiliyeti olan 4 ilçede (Serik, Kumluca, Aksu ve Gazipaşa) gerçekleştirilmiştir.

Anket uygulaması sonucunda farklı genişlikteki işletmeler arasında farklıı̆̆ ortaya koymak amacıyla işletmeler; 0-3 dekar arasında ki işletmeler 1. grup, 3.17.5 dekar arasında ki işletmeler 2. grup, 7.6 + ve üzeri dekara sahip işletmeler 3. grup olarak sınıflandırılmıştır. Bu çalışmada işletme grupları aşağıda gösterildiği gibi işletme büyüklüklerine göre sınıflandırılmış olup, çalışmanın sonraki bölümlerinde bazı araştırma bulgularının gösteriminde bu gruplandırmalar kullanılmıştır. Antalya ilinde örtüaltı sebze üreticilerinin tohumluk tercihlerini etkileyen faktörlerin belirlenmesi ve bu faktörle arasındaki ilişkilerin tespitini amaçlayan bu çalışmada, kullanılan birincil veriler, Antalya ilinde örtüaltı sebze üretiminin ekim alanı açısından yarısından fazlasının yapıldığı (\%57) dört ilçe olan Kumluca, Serik, Aksu ve Gazipaşa ilçelerinde sebze üretiminde faaliyet 
gösteren tarımsal işletmelerden toplanmıştır. Belirtilen 4 ilçede üreticiler ile yüz yüze anket yapılarak veriler elde edilmiştir. Güvenirliği test edilen anketlerin basımı gerçekleştirilmiş ve anket yapılması saptanan ilçelere oransal yöntemle dağıtılıp, örtüaltı sebze üretimi yapan işletmelerden rastgele seçilen üreticilerle anket yapılmıştır.

Bu çalışmada, Antalya ilinde örtüaltı sebze üreticileriyle yüz yüze anket yöntemi ile toplanan verilerin değerlendirilmesinde SPSS programı kullanılmıştır. Anketlerden elde edilen bu veriler, örtüaltı sebze üreticilerin tohumluk tercihlerini etkileyen faktörlerin tespitinde ve bu faktörler arasındaki ilişkileri tespit etmede kullanılmıştır. Belirlenen faktörler arasındaki ilişkilerin tespitinde toplanan verilere ait özellikler belirlenerek, bu özelliklerin her biri için birbiri arasında fark olup olmadığı Ki-Kare testiyle belirlenmiştir. Ki-kare analizinde kesikli veriler (cinsiyet, eğitim, yenilikleri uygulama davranışları vb.) Ki-kare testine tabi tutularak, bu değişkenler arasında farklılık olup olmadığı incelenmiştir. Ayrıca sebze üreticilerine sorulan çeşitli sorulara verilen cevaplar da çizelge ve şekiller haline getirilerek yorumlanmıştır.

\section{BULGULAR ve TARTIŞMA}

Araştırma kapsamında görüşülen çiftçilerin yaşı genel olarak işletmelerde ortalama 41.63 'tür. 1 . ve 3 . grup işletmelerde çiftçilerin yaş ortalamaları birbirine yakındır. Bu durum 2. grup işletmelerde ise üretici yaşları ortalamasının 43.51 olduğu tespit edilmiştir.

Genel olarak işletmelerde görüşülen üreticilerin \%95.83'ü erkek, \%4.17'sinin ise kadın olduğu tespit edilmiştir. Buna göre görüşme yapılan üreticilerin büyük bir çoğunluğu erkek bireylerden oluşmaktadır. Ayrıca görüşme yapılan kadın çiftçi en fazla 1 . grup işletmelerde yer almaktadır.

Eğitim seviyesi en yüksek olan ilçe Gazipaşa iken, eğitim seviyesi en düşük ilçe Aksu ilçesinin olduğu belirlenmiştir. Buna göre Gazipaşa ilçesinde ailelerin eğitime daha fazla önem gösterdikleri, çocuklarını okutma konusunda daha bilinçli oldukları söylenebilmektedir.

Genel olarak işletmelerde üreticilerin ortalama eğitim seviyesinin 8.25 yıl olduğu tespit edilmiştir. İşletme grupları itibariyle incelendiğinde, diğer işletme gruplarına göre 3 . grup işletmelerde eğitim durumunun daha yüksek olduğu belirlenmiştir.

Incelenen işletmelerde işletmecilerin çiftçilik deneyimi ortalama 19.95 yıl sebze yetiştiriciliği deneyimleri ise 19.69 yıl olarak bulunmuştur. Ayrıca işletme grubu büyüdükçe işletmecilerin çiftçilik ve sebze yetiştiriciliği deneyim sürelerinin arttığı tespit edilmiştir.

Görüşme yapılan işletmelerde işletmecilerin sahip olduğu ortalama aile büyüklüğü 4.25 kişi olarak belirlenmiştir. Bu durum 1. 2. ve 3. grup işletmelerde sırasıyla $4.06,4.43$ ve 4.22 olduğu saptanmıştır.

Araştırma kapsamında görüşülen 96 üreticinin 83 kişisi (\%86.46) sadece tarımsal faaliyetlerle uğraşırken, 13 kişisi (\%13.54) tarım dışı faaliyetlerle de uğraştığı tespit edilmiştir. Ayrıca tarım dışı faaliyetlerle uğraşan üreticilerin 3. grup işletmelerde fazla olduğu belirlenmiştir.

Sadece tarımsal faaliyetlerle uğraşan çiftçilerin \%56.63'ünün gelir durumunu orta düzeyde gördüğü, \%42.17'sinin düşük, \%1.20'sinin ise yüksek düzeyde gördüğü tespit edilmiştir. Genel olarak işletmelerde ve işletme gruplarında işletmecilerin çoğunun tarımsal gelirlerini orta düzeyde gördükleri belirlenmiştir.

İşletmecilerin sosyal güvencesinin olup olmama durumu incelendiğinde \%80.21'inin sosyal güvencesinin olduğu, \%19.79'unun olmadığı görülmektedir. Ayrıca diğer işletme gruplarına göre 2. grup işletmelerde daha fazla işletmecinin sosyal güvencesinin olduğu saptanmıştır.

Araştırma kapsamında görüşülen çiftçilerin \%56.25'i köylerde, \%43.75'i ilçe merkezlerinde yaşamakta olduğu belirlenmiştir. İşletme grupları itibariyle incelendiğinde 3. grup işletmelerdeki üreticilerin çoğunun köylerde yaşamakta olduğu saptanmıştır. Bu durumun tarım alanı büyüdükçe kırsal alana kayması durumuyla ilişkilendirilebilir.

Araştırma kapsamında görüşülen işletmelerin çoğunun yani \%96.88'nin aile işletmesi olduğu tespit edilmiştir. Ayrıca işletmelerin \%3.13'nün de anonim şirketi statüsünde olduğu belirlenmiştir.

Örtüaltında sebze üretim faaliyetinde bulunan işletmelerin arazi varlığı ve kullanım durumu incelendiğinde; işletme başına 13.91 da toplam işletme arazisi, 7.36 da işlenen arazi, 6.55 da kullanılmayan alan ve 7.36 da örtüaltı alan düştüğü tespit edilmiştir. Tüm işletmeler ortalamasına göre işletme arazisinin mülkiyet durumuna bakıldığında işletme başına düşen mülk, ortak ve kira arazisi miktarları sırasıyla $12.59 \mathrm{da}, 0.59$ da ve 0.73 da olarak bulunmuştur.

Genel olarak işletmelerde örtüaltı sebze üretiminden elde edilen ortalama gayri safi üretim değerinin 105.990 TL olduğu belirlenmiştir. İşletme grupları itibariyle incelendiğinde işletme grubu büyüdükçe gayri safi üretim değerinin de orantılı olarak arttığı tespit edilmiştir.

Görüşme yapılan işletmelere "önümüzdeki yıllarda sebze üretim miktarında nasıl bir değişiklik bekliyorsunuz" diye sorulmuş verilen cevaplar Çizelge 4 'te düzenlenmiştir. 
Genel olarak işletmelerde üreticilerin \%70.83'ü değişiklik olmayacağını ifade etmişlerdir. Bunun yanında üreticilerin $\% 17.71^{\prime} i$ üretim miktarının azalacağını, $\% 11.46$ 'sı ise artacağını dile getirmiştir.

Üreticilere "gelecekte örtüaltı sebze üretiminden elde edeceğiniz gelirde nasıl bir değişiklik bekliyorsunuz" diye sorulmuş buna göre üreticilerin büyük bir çoğunluğu, yani \%67.71'i gelecekte elde edeceği gelir miktarının değişmeyeceğini, \%29.17'si azalacağını, \%3.13'ü artacağını ifade etmişlerdir. Tüm işletme gruplarında üreticilerin çoğu elde edecekleri gelirin değişmeyeceğini söylerken, 1., 2. ve 3. grupta sırasıyla üreticilerin \%27.27'si, \%32.43'ü ve \%17.39'u azalacağını söyledikleri belirlenmiştir.

İşletmelerde üreticilerin örtüaltı sebze yetiştiriciliğini tercih nedenleri incelendiğinde, üreticilerin çoğunun (\%78.13) geleneksel üretim alışkanlığı nedeniyle, \%70.83'ü arazi ve iklim koşullarının uygun olduğundan dolayı tercih ettiği tespit edilmiştir. Bunun yanında üreticiler aile tüketimi, karlı olması, aile işgücünü değerlendirme ve ürün çeşitlendirmesine giderek risk ve belirsizliği azaltma nedenleriyle tercih ettikleri saptanmıştır.

Araştırma kapsamında görüşülen üreticilere "yeni bir uygulamaya karşı davranışınız nasıl olur" diye sorulmuş, üreticilerin $\% 36.46$ 'sı yenilik başarılı olursa uygulayacağını, \%34.36'sı önce deneme yapıp sonra uygulayacağını ifade etmişlerdir. Bunun yanında \%17.75'i yeniliği uygulayanların sonuçlarına bakıp öyle uygulayacağı, \%10.42'sinin ise hemen uygulayacağı belirlenmiştir.

Üreticilerin çoğu yani \%71.9'u hastalık ve zararlılarla mücadele konusunda bilgi ihtiyacı duyarken, $\% 43.8^{\prime} \mathrm{i}$ gübreleme, \%11.5'i sulama, \%10.4'ü yetiştiricilik bilgileri ve $\% 19.8$ 'i diğer konularda bilgiye intiyaç duydukları saptanmıştır.

Örtü altı sebze üretimi entansif tarım özelliği göstermesi, tarımsal faaliyetlerin küreselleşmesiyle birlikte, hastalık ve zararlılarla ilgili birçok gelişme ortaya çıktığından dolayı üreticilerin bu sorunların çözümüne yönelik bilgi ihtiyacı artmakta olduğu söylenebilir.

Öztürk (2010), yapmış olduğu yüksek lisans tez çalışmasında, başarısız olduklarını düşünen işletmelerin (\%14.67), mevcut durumu açıllarken var olan durum ile ilgili büyük oranda teknik bilgi yetersizliğinden (\%63.64) söz konusu durumun ortaya çıktığını bildirmiştir. Başarısızlıkların bir diğer nedeninin de yeterli miktarda ilaç alınmasının söz konusu olamaması (\%18.18) ve ilaçların etkinliğinin yeteri kadar iyi olmamasından (\%18.18) kaynaklandığını dile getirmiştir. Dolayısıyla, çalışmanın bulguları, örnek çalışma sonuçlarıyla paralellik göstermektedir.
Örtü altı sebze yetiştiriciliği yapan üreticiler önceden tohum alıp toprağa direk tohumu ekerken, günümüzde daha çok profesyonel fide firmalarından satın alınan fideleri toprağa dikmektedirler. Örtüaltı sebze yetiştiriciliği yapan üreticiler dikecek oldukları sebzenin öncelikle hangi tür olacağına daha sonra da bu türde var olan çeşitlere karar vermek durumundadırlar. Araştırma kapsamında görüşülen çiftçilere bu konuda nasıl karar verdikleri sorulmuştur.

Üreticilerin \%90.65'inin kendisinin karar verdiği görülmekte olup, bunu \%33.33 ile diğer çiftçilere soran üreticiler, \%20.83 ile fideliklere sorması takip etmektedir.

Üreticinin kendi karar veriyor olması aslında, nihai olarak tüm sorgularını bitirdikten sonra, işletmecinin, kararlarını verirken, zorunlu olarak başkalarına bağlı olmadıklarının bir göstergesi olarak bu seçeneği seçtikleri düşünülmektedir. Görüşme yapılan çiftçilerin büyük bir çoğunluğu kendi karar verirken, bir kısmı kendi iradesi dışında tamamen dışa bağımlı olarak dikeceği sebze türünü belirlemektedir. Bu durum; borçlu olduğu bayinin, komisyoncunun ya da sera kiracısının vereceği fideye razı olunması gibi bir durumla açıklanabilir.

Kendi karar vermesi konusunda çeşit seçiminde de benzer durum geçerlidir. Ankete katılanların \%89.58'i kendisi karar verirken, diğerleri kendi iradesi dışında tamamen dışa bağımlı olarak dikeceği sebze çeşidine karar vermektedir. Çeşide karar verme konusunda türden farklı olarak, üreticilerin \%35.42'si diğer çiftçilere danışırken, bunu \%16.67 ile bayilerde çalışan teknik personele danışan üreticilerin takip ettiği belirlenmiştir (Çizelge 3).

Çizelge 3. Üreticilerin sebze çeşidi tercihinde referans kaynakları

Table 3. Reference sources for the producers' choice of variety

\begin{tabular}{lcc}
\hline Referans kaynakları & Sayı & $\%$ \\
\hline Kendi deneyimi & 86 & 89.58 \\
Diğer çiftçilere soruyor & 34 & 35.42 \\
Zirai ilaç gübre bayi teknik elemanına & 16 & 16.67 \\
soruyor & 12 & 12.50 \\
Fideliklere soruyor & 7 & 7.29 \\
Zirai ilaç gübre bayi sahiplerine & & 4.17 \\
soruyor & 2 & 2.08 \\
Komisyoncu önerisi ve yönlendirmesi & 1 & 1.04 \\
İhracatçıya soruyor & & \\
Özel danışmana soruyor &
\end{tabular}

Araştırma kapsamında görüşülen çiftçilere en son örtüaltında yetiştirdiğiniz sebze tohumu çeşidinden 
memnuniyet durumları sorulduğunda üreticilerin çoğunun (\%75.00) tohum çeşidinden memnun olduğu belirlenmiştir.

Üreticilere "bir sonraki dönmede yetiştirmeyi düşündüğünüz tohum çeşidinde dikkate aldığınız hususlar nelerdir" diye sorulmuş, alınan cevaplar Çizelge 4 'te oransal olarak verilmiştir. Buna göre üreticilerin \%90.63'ü veriminin yüksek olmasına, \%88.54'ü kalitesinin yüksek olmasına, \%70.83'ü hastalık ve zararlılara karşı dayanıklı olmasına dikkat ettikleri belirlenmiştir (Çizelge 4). Üreticilerin dikkat ettiği diğer hususların ise alışkanlığı, pazarlama imkânının iyi olması, herkes tarafından kullanılma durumu ve fiyatının ucuz olması gibi hususlar olduğu tespit edilmiştir.

Çizelge 4. Üreticilerin bir sonraki dönemde örtüaltında yetiştirecekleri tohum çeşidine karar verirken dikkat ettikleri hususlar

Table 4. The issues that producers pay attention to when deciding on the seed type to grow under greenhouse in the next period

\begin{tabular}{lcc}
\hline Hususlar & Sayı & $\%$ \\
\hline Verimi yüksek & 87 & 90.63 \\
Kalitesi yüksek & 85 & 88.54 \\
Hastalık ve zararlılara karşı dayanıklı & 68 & 70.83 \\
Alışkanlıklar & 42 & 43.75 \\
Pazarlama imkânı iyi & 26 & 27.08 \\
Herkes tarafından kullanııma durumu & 4 & 4.17 \\
Fiyatı ucuz & 2 & 2.08 \\
\hline
\end{tabular}

*Birden fazla cevap verilmiştir.

İncelenen işletmelerde üreticilerin üretimde karşılaştıkları sorunların başında \%96.89 ile girdilerin pahalı olması gelmektedir. Bunu \%58.33 ile hastalık ve zararlılar takip etmektedir. Üreticilerin diğer sorunları pazarlama sorunu ve teknik bilgi eksikliği olduğu saptanmıştır. Üreticilerin örtüaltı sebzelerin pazarlanmasında karşılaştığı sorunların başında \%87.50 ile ürün fiyatlarının düşük olması gelmektedir. Bunu $\% 62.50$ ile pazar yapısının düzensiz olması takip etmektedir. Üreticilerin diğer pazarlama sorunları sırasıyla istediği zaman alıcı bulamama, veresiye satış, ürün işleme ve değerlendirme tesislerinin yetersiz olması geldiği tespit edilmiştir.

Incelenen işletmelerde üreticilerin örtüaltında sebze yetiştiriciliği ile ilgili devletten beklentileri sorulduğunda, üreticilerin \%31.25'i girdi fiyatlarının düşürülmesi, \%22.92'si yeni pazarlar oluşturulması, \%12.50'si ihracatın arttırılması, \%12.50'si üreticiye desteklerin verilmesi konularında devletten beklentileri olduğunu belirtmişlerdir.

Araştırmada anket görüşmesi aşamasında işletmelere sebze tohumu tercihlerine yönelik 5 'li likert ölçeğinde 35 adet yargı cümlesine cevap vermeleri istenmiş olup verilen cevapların ortalaması alınarak sonuçlar Çizelge 5'de incelenmiştir. Yargı cümlelerinin ortalamaları 5'e yaklaştıkça katılımın arttığını, 1'e yaklaştıkça katılımın azaldığını göstermektedir. Buna göre işletmelerin verdikleri cevapların ortalamalarına bakıldığında 15 tanesi 4 ve üzeri, 2 tanesi ise 2 ve altında yer aldığı belirlenmiştir. Ortalaması 4 ve üzerinde olanlara bakıldığında girdi fiyatının yüksek olması, sektörün bölge açısından önemi, Ar-Ge'nin düşük olması, ürünün değerlendirmesinde karşılaşılan sorunlar, örgütlenmenin düşük olması ve bilgilendirilmenin düşük olması gibi faktörler üreticilerin yoğun olarak katıldığı yargı cümlelerinin olduğu bulunmuştur. Ayrıca kamuoyundaki sebze tarımı hakkındaki yanlış bilgiler hakkındaki bilgi sahibi olma ve ürün fiyatlarının yüksek olmasının yüksek kardan kaynaklandığı yorumları ise üzerinde en az birleşilen yargı cümleleri arasında yer aldığı tespit edilmiştir.

Çizelge 5. İşletmelerin sebze tohumu tercihlerine yönelik bazı yargı cümlelerine katılımı

Table 5. Thoughts of enterprises on vegetable seed preferences

\begin{tabular}{lll} 
No & Yargı Cümleleri & Ort. \\
\hline 1. & Örtüaltı sebze üretiminde en büyük sorun girdi fiyatlarının yüksek olmasıdır. \\
2. & Üretilen örtüaltı sebzenin fiyatı, tüketiciler açısından yüksek bulunmaktadır. & 4.8 \\
3. & Antalya ilinde örtüaltı sebze üretimi iç pazarda rekabet açısından yeterli düzeydedir. & 4.7 \\
4. & Örtüaltı sebze yetiştiriciliğinde Türkiye'yi zor durumda bırakan dış dinamiklerdir. & 4.7 \\
5. & Antalya ilinde örtüaltı sebze üretimi önümüzdeki yıllarda daha büyük sorunlar yaşayacaktır. \\
6. & Türkiye, örtüaltı sebze üretimi açısından kapasitesini arttırabilecek düzeye sahiptir. \\
7. & Antalya ilindeki örtüaltı sebze üretici sayısı fazladır. \\
8. & Bölgede örtüaltı sebzecilik için fide temininde herhangi bir sorun yaşanmamaktadır. \\
9. & Sebze yetiştiricileri, danıştıkları üreticilerin hangi sebze çeşitleri yetiştirdiğini önemser. & 4.7
\end{tabular}


Çizelge 5 (devamı)

10. Örtüaltı sebze tohumu ile ilgili Ar-Ge çalışmaları yeterli düzeyde değildir. 4.3

11. Antalya ili, örtüaltı sebze üretimi yapmak için yeni sera alanları açısından yeterlidir.

12. Bölgedeki sivil toplum kuruluşlarının sebze üretimine yönelik çalışmaları yetersizdir.

13. Ürünlerin sanayide değerlendirme düzeyi yeterli değildir.

14. Antalya ilinde örtüaltı sebze üreticileri, mevcut üretici örgütlerinden yeterince yararlanamamaktadır.

15. Örtüaltı sebze üretimine yönelik bilgilendirme eğitimleri yetersizdir.

16. Örtüaltı sebze seralarının modernizasyonu yeterince yapılmamaktadır.

17. Örtüaltı sebze üretiminde üreticiler Sosyal Medya'yı yeterince kullanmamaktadır.

18. Antalya ilinde mevcut sebze depolama tesis kapasitesi yeterli değildir.

19. Üreticiler genellikle yerli firmaların tohumlarını tercih etmemektedirler.

20. Antalya ilinde sadece örtüaltı sebze üretimi yaparak geçim sağlanabilir.

21. Tüketiciler yabancı menşeili tohumları tercih etmektedirler.

22. Üreticilerin sebze üretimi ile ilgili bilgi düzeyleri yeterlidir.

23. Örtüaltı sebze yetiştiricileri sebze çeşidi hakkında karar verirken fide şirketlerinden etkilenmez.

24. Üreticiler pazara yönelik sebze çeşitleri hakkında yeterli bilgiye sahiptir.

25. Örtüaltı sebze yetiştiricileri sebze çeşidi hakkında karar verirken bayiden etkilenmez.

26. Aşırı ilaç kullanımı örtüaltı sebze ürünlerinin ihracatı açısından sorun olmaya başlamıştır.

27. Antalya örtüaltı sebzecilikte ilaç kullanım düzeyi olması gerekenden daha yüksektir.

28. Sebze üreticileri, yeni sebze çeşitleri ile ilgili yeterince bilgiye sahiptirler.

29. Antalya ilindeki örtüaltı sebze üreticilerinin ulusal/uluslararası fuarları ziyaret düzeyi yüksektir.

30. Organik örtüaltı sebze üretimi, bölgedeki sebze üretiminin sorunları için bir çözüm olabilir.

31. Türkiye'de yerli hibrit tohum çalışmaları ihtiyacı karşılayacak düzeydedir.

32. Hastalık ve zararlılarla mücadele konusunda devlet kurumlarının verdiği hizmetler yeterlidir.

33. Antalya ilinde üretilen örtüaltı sebze çeşitleri ihracat için uygun değildir.

34. Örtüaltı sebzeciliğindeki olumsuz ve yanlış bilgiler hakkında kamuoyu yeterince bilgi sahibidir.

35. Üretilen örtüaltı sebzenin fiyatının yüksek olması, üreticinin yüksek kar elde ediyor olmasındandır.

5: Kesinlikle katılıyorum, 4: Katılıyorum, 3: Kararsızım, 2: Katılmıyorum, 1.Kesinlikle katılmıyorum

Antalya ilinde örtüaltı sebze üretimiyle uğraşan üreticilere sorulan sorulardan elde edilen verilerdeki bazı değişkenler arasında ilişkileri tespit etmek için Ki-kare istatistiki analiz yapılmıştır. Belirlenen faktörler arasındaki ilişkilerin tespitinde toplanan verilere ait özellikler belirlenerek, bu özelliklerin her biri için birbiri arasında fark olup olmadığı Ki-Kare testiyle belirlenmiştir. Ki-kare analizinde kesikli veriler (eğitim, işletme genişliği, yenilikleri uygulama davranışları vb.) Kikare testine tabi tutularak bu değişkenler arasında farklılık olup olmadığı incelenmiştir.

Çalışmada işletme grupları arasında üreticilerin eğitim düzeyleri bakımından farklııı̆ın olup olmadığının belirlenmesi amacıyla Ki-kare testi yapılmıştır (Çizelge 6). Hesaplanan $\chi^{2}$ istatistiği 15.604 olup bu değer 0.05 olasılıkla önemli bulunmuştur $(P<0.05)$.
Çizelge 6. İşletme gruplarının eğitim durumları ile ilgili ilişkileri

Table 6. Relationships of enterprises groups with their educational level

\begin{tabular}{lcccccc}
\hline $\begin{array}{l}\text { Işletme } \\
\text { büyüklüğüne } \\
\text { göre gruplar }\end{array}$ & $\mathbf{5 , 0 0}$ & $\mathbf{8 , 0 0}$ & $\mathbf{1 2 , 0 0}$ & $\mathbf{1 6 , 0 0}$ & $\mathbf{1 8 , 0 0}$ & Toplam \\
\cline { 2 - 6 } & 19 & 10 & 7 & 0 & 0 & 36 \\
I. Grup & 21 & 5 & 7 & 4 & 0 & 37 \\
II. Grup & 6 & 4 & 8 & 4 & 1 & 23 \\
III. Grup & 46 & 19 & 22 & 8 & 1 & 96 \\
Toplam & $\chi^{2}=15.604$ & \multicolumn{5}{c}{$\mathrm{P}=0.048$} \\
\hline
\end{tabular}

Örtüaltı sebze yetiştiriciliğinde yenilikler ile ilgili davranış şekillerinin işletme büyüklüğüne göre ilişkisi Ki-kare analiziyle incelenmiştir. Sonuçlara göre iki değişken 
arasında istatistiki olarak anlamlı bir ilişki olduğu tespit edilememiştir.

Örtüaltı sebze yetiştiriciliğinde ekim alanı gruplarına göre yeniliklere karşı yaklaşımlar Ki-kare analiziyle incelendiğinde iki değişken arasında istatistiki olarak anlamlı bir ilişki olduğu tespit edilememiştir.

\section{SONUÇ ve ÖNERILER}

Incelenen işletmelerde, çiftçilerin ortalama yaşının 41.63 yıl, çiftçilik deneyimlerinin 19.95 yıl ve sebze yetiştiriciliği deneyimlerinin 19.69 yıl olduğu tespit edilmiştir. Bunun yanında görüşme yapılan üreticilerin \%95.83'ünün erkek, \%4.17'sinin ise kadın olduğu belirlenmiştir. Üreticilerin eğitim düzeylerinin ortalamada 8.25 yıl olduğu, eğitim düzeyinin yüksek olduğu üreticilerin Gazipaşa ilçesinde bulunduğu tespit edilmiştir.

İşletmelerde üreticilerin sahip olduğu ortalama aile büyüklüğü 4.25 kişi olarak belirlenmiştir. Hane büyüklüğü 1. 2. ve 3 . grup işletmelerde sırasıyla 4.06 , 4.43 ve 4.22 kişi olduğu tespit edilmiştir. Görüşme yapılan 96 üreticinin 83 kişisi (\%86.46) sadece tarımsal faaliyetlerle uğraşırken, 13 kişisi (\%13.54) tarım dışı faaliyetlerle de uğraştığı tespit edilmiştir. Ayrıca tarım dışı faaliyetlerle uğraşan üreticilerin 3. grup işletmelerde fazla olduğu belirlenmiştir. Bunun yanında sadece tarımsal faaliyetlerle uğraşan çiftçilerin \%56.63'ünün gelir durumunu orta düzeyde gördüğü, \%42.17'sinin düşük, \%1.20'sinin ise yüksek düzeyde olduğunu ifade etmişlerdir.

Üreticilerin \%80.21'inin sosyal güvencesinin olduğu, \%19.79'unun ise olmadığı belirlenmiştir. Bununla birlikte, üreticilerin \%56.25'inin köylerde, \%43.75'inin ise ilçe merkezlerinde yaşamakta olduğu tespit edilmiştir.

Üreticilerin örtüaltı sebze yetiştiriciliğini tercih nedenlerinin başında (\%78.13) geleneksel üretim alışkanlığı ve \%70.83'ü arazi ve iklim koşullarının uygun olması gelmektedir.

Örtüaltı sebze üretimi ile ilgili yeni bir uygulamaya üreticilerin \%36.46'sı yenilik başarılı olursa uygulayacağını, \%34.36'sı ise önce deneme yapıp sonra uygulayacağını ifade etmişlerdir. Üreticilerin örtüaltı sebze yetiştiriciliğinde bilgiye intiyaç duyduğu konuların başında \%71.90 ile hastalık ve zararlılarla mücadele gelmektedir. Bunu $\% 43.80$ ile gübreleme, $\% 11.50$ ile sulama, \%10.40 ile yetiştiricilik bilgileri ve \%19.80 ile diğer konular takip etmektedir.

Örtüaltı sebze yetiştiriciliği yapan üreticiler dikecek oldukları sebzenin öncelikle hangi tür olacağına daha sonra da bu türde var olan çeşitlere karar vermek durumundadırlar. Görüşülen üreticilerin $\% 90.65$ 'i sebze türüne kendisi karar vermektedir. Bunu \%33.33 ile diğer çiftçilere soran üreticiler, \%20.83 ile fideliklere soran üreticiler takip etmektedir. Sebze çeşidine üreticilerin \%89.58'i kendisi karar vermektedir. Diğerleri kendi iradesi dışında tamamen dışa bağımlı olarak üreteceği sebze çeşidine karar vermektedir.

Incelenen işletmelerde, üreticilerin çoğu (\%75.00'ının) yetiştirdikleri tohum çeşidinden memnun olduklarını, \%17.71'i ise memnun olmadığını bildirmiştir.

Görüşülen üreticilerin $\% 31.25^{\prime} i$ girdi fiyatlarının düşürülmesi, \%22.92'si yeni pazarlar oluşturulması, \%12.50'si ihracatın arttırılması, \%12.50'si ise desteklerin verilmesi gerektiğini ifade etmişlerdir.

Bu sonuçlara göre, Antalya ilinde, üreticilerin tohum tercihini etkileyen faktörlerin tespit edilmesine yönelik yapılan bu çalışmadan elde edilecek sonuçlara göre geliştirilen bazı öneriler aşağıdaki gibi sıralanabilir;

- Bölgede örtüaltı sebze üretiminde en çok bilgi ihtiyacı olarak tespit edilen hastalık ve zararlılarla mücadeleye yönelik eğitim ve yayım çalışmalarının arttırılması üreticilerin bilinçlenmesinde faydalı olacaktır.

- Örtüaltı sebze yetiştiriciliğinde üreticinin sebze tür ve çeşidine karar vermede hala bağımsız olarak kendisinin karar verebildiği, üreticilerin bağımsız hareket etme düzeyinin yüksek olduğunu tespit edilmiştir. Bu durumun devam edebilmesi için politikalar geliştirilmesi gereklidir.

- Örtüaltı üretiminde yoğun olarak kullanılan girdilerin çoğunun dövize bağlı olması nedeniyle, girdi fiyatlarında sezon içerisinde meydana gelen fiyat artışının üreticiye olumsuz etkisinin azaltılması için girdi temininde önlemler alınması gerekmektedir.

- Örtüaltı üretiminde tüketicilerin kamuoyu nezdinde yanlış bilgilere sahip olmaları, üreticilerin daha iyi kazanç elde etmelerinde bir engel olarak görüldüğünden dolayı genetiği değiştirilmiş organizma (GDO), hormon, hibrit gibi tarımda en çok konuşulan konuların kamuoyuna daha iyi anlatılması önem taşımaktadır.

Piyasaya arz edilen sebzenin az olduğu dönemlerde genellikle sebze fiyatları yüksektir. Bu durumun üreticilerin çok kazandığı gibi bir yanlış algı sebze üreticisine zarar vermektedir. Bu algının ortadan kaldırılması için tüm paydaşların iş birliği içinde olmaları gerekmektedir.

\section{ÖZET}

Amaç: Bu çalışmada, Antalya ilinin Serik, Aksu, Kumluca ve Gazipaşa ilçelerinde örtüaltında sebze yetiştiriciliği yapan işletmelerin kullandıkları tohum ve fide 
tercihlerini belirlenmesi ve tohum ya da fide tercihlerini etkileyen faktörlerin ortaya konulması amaçlanmıştır.

Yöntem ve Bulgular: Araştırmanın ana materyalini Antalya ilinin Serik, Aksu, Kumluca ve Gazipaşa ilçelerinde örtüaltında sebze yetiştiriciliği yapan 96 işletmede üreticilerle yapılan anket çalışması ile toplanmış veriler oluşturmaktadır. Araştırmada işletme genişlikleri 0-3 dekar, 3.1-7.5 dekar, 7.6 ve daha fazla dekar örtüaltı alana sahip olan işletmeler olmak üzere 3 gruba ayrılmıştır. Araştırma sonuçlarına göre, incelenen işletmelerde örtüaltında sebze yetiştirilen alanının ortalama 7.36 dekar, üreticilerin ortalama yaşının 41.63 yıl ve sebze yetiştiriciliği deneyim süresinin 19.69 yıl olduğu tespit edilmiştir. İşletmelerde en fazla üretilen sebze türünün domates olduğu (\%54.16), bunu sırasıyla biber (\%34.38), hıyar (\%30.21) ve diğer sebzelerin (\%15.63) izlediği belirlenmiştir. Üreticilerin örtüaltı sebze yetiştiriciliğini tercih nedenlerinin başında (\%78.13) geleneksel üretim alışkanlığı, \%70.83'ü arazi ve iklim koşullarının uygun olması gelmektedir. İşletmelerde örtüaltı sebze yetiştiriciliğinde üreticilerin \%85.45'nin bilgiye ihtiyacının olduğu, \%14.58'nin ise olmadığı belirlenmiştir. Bilgiye ihtiyacı olan üreticilerin \%79.17'sinin ziraat mühendisi/teknikerinden, \%70.83'ünün diğer çiftçilerden bilgi aldığı tespit edilmiştir. Ayrıca işletmelerde üreticilerin üretimde karşılaştıkları sorunların başında \%96.89 ile girdilerin pahalı olması gelmekte, bunu \%58.33 ile hastalık ve zararlılar takip ettiği belirlenmiştir. Bunun yanında üreticilerin sebzelerin pazarlanmasında karşılaştığı sorunların başında da \%87.50 ile ürün fiyatlarının düşük olması gelmekte, bunu \%62.50 ile pazar yapısının düzensiz olması takip etmektedir.

Genel Yorum: Örtüaltı sebze yetiştiriciliği yapan üreticiler dikecek oldukları sebzenin öncelikle hangi tür olacağına daha sonra da bu türde var olan çeşitlere karar vermek durumundadırlar. Görüşülen üreticilerin \%90.65'inin sebze türüne kendisinin karar verdiği görülmekte olup, bunu \%33.33 ile diğer çiftçilere soran üreticiler, \%20.83 ile fideliklere soran üreticiler takip etmektedir. Bununla birlikte ürün çeşidine üreticilerin \%89.58'i kendisi karar verirken diğerleri kendi iradesi dışında tamamen dışa bağımlı olarak dikeceği sebze çeşidine karar vermektedir. Ayrıca üreticilerin çoğunun (\%75) yetiştirdikleri çeşitten memnun olduğu belirlenmiştir. Bunun yanında üreticilerin \%17.71'nin memnun olmadığı ve \%7.29'unun ise çok memnun olduğu tespit edilmiştir.

Çalışmanın Önemi ve Etkisi: Antalya ilinde örtüaltı sebze üreticilerinin tohumluk tercihlerini etkileyen faktörlerin belirlenmesi ve bu faktörle arasındaki ilişkilerin tespit edilmesi.
Anahtar Kelimeler: Tohumculuk, çeşit tercihi, örtüaltı sebze yetiştiriciliği, üretici tercihleri, Antalya.

\section{TEŞEKKÜR}

Bu çalışma, Süleyman Demirel Üniversitesi, Fen Bilimleri Enstitüsü, Tarım Ekonomisi Anabilim Dalı'nda hazırlanan Yüksek Lisans tezinin bir bölümüdür. Yüksek lisans tez çalışmamızı 4879-YL1-17 Nolu Proje kodu ile destekleyen Süleyman Demirel Üniversitesi Bilimsel Araştırma Projeleri Yönetim Birimi Başkanlığına teşekkür ederiz.

\section{ÇIKAR ÇATIŞMA BEYANI}

Yazar(lar) çalışma konusunda çıkar çatışmasının olmadığını beyan eder.

\section{ARAŞTIRMACILARIN KATKI ORANI BEYANI}

Yazarlar çalışmaya eşit oranda katkı sağlamış olduklarını beyan eder.

\section{KAYNAKLAR}

Akdoğan I (2005) Türkiye'de Tohumluk Üretim, Dağıtım ve Kullanımında Üretici Örgütlerinin Rolü. Yüksek Lisans Semineri, Ankara Üniversitesi, Fen Bilimleri Enstitüsü.

Anonim (2014) Onuncu Kalkınma Planı, Bitkisel Üretim Özel Ihtisas Komisyon Raporu. Ankara.

Balcı EF (1993) Türkiye'de Bitkisel Tohumculuğun Genel ve Tarım İşletmeleri Düzeyindeki Sorunları Üzerine Bir Araştırma (Aşağı Seyhan Ovası Örneği). Yüksek Lisans Tezi, Çukurova Üniversitesi, Fen Bilimleri Enstitüsü.

Balkayan A, Duman I, Engiz M, Ermiş S, Onus AN, Özcan M, Çelikel F, Demir I, Kandemir D, Özer M (2015) Bahçe Bitkileri Tohumluğu Üretimi ve Kullanımında Değişimler ve Yeni Arayışlar. TMMOB Ziraat Müh. Odası VIII. Türkiye Ziraat Müh. Teknik Kongresi, Ankara.

Başbuğ T, Gül M (2016) Analysis of Cost and Profitability for Enterprises Engaged in Greenhouse Cultivation in Highland Conditions: The Case of Elmalı, Antalya. Scientific Papers Series Management, Economic Engineering in Agriculture and Rural Development, 16 (2): 19-26.

Demir I, Balkaya A, Yılmaz K, Onus AN, Uyanık M, Kaycıoğlu M, Bozkurt M (2010) Sebzelerde Tohumluk ve Fide Üretimi. TMMOB Ziraat Müh. Odası VII. Türkiye Ziraat Müh. Teknik Kongresi, Ankara, 8778.

Demirtaş B, Keleş D (2005) Çukurova Bölgesinde Sebze Tohumculuğunun Pazarlama Yapısı. Türkiye II. 
Tohumculuk Kongresi. Çukurova Üniversitesi Ziraat Fakültesi, Adana, 45.

Emekli Y, Kendirli B, Kurunç A (2010) Structural analysis and functional characteristics of greenhouses in the Mediterranean region of Turkey. African Journal of Biotechnology Vol. 9(21), pp. 3131-3139.

Fert C (2004) Antalya İli Sebze Tohumu Yetiştiriciliğinin Üretim Ve Pazarlama Yapısının İncelenmesi. Yüksek Lisans Tezi, Akdeniz Üniversitesi, Fen Bilimleri Enstitüsü.

Gerger F, Karlı B (1999) Şanlıurfa İli Merkez İlçe Sebze İşletmelerinin Ekonomik Analizi ve Pazarlama Sorunları. GAP I. Tarım Kongresi. Harran Üniversitesi Ziraat Fakültesi, Şanlıurfa, 339-346.

Gül H, Gül M, Acun S, Aslan ST, Öztürk A, Kara B, Akman Z (2015) Tarım işletmelerinde buğday tohumu kullanımı ve sorunları: Burdur ve Isparta illeri örneği. Türk Tarım-Gıda Bilim ve Teknoloji Dergisi, 3(9): 732-741.

Güngör H, Saraçoğlu KC, Güngör G (2016) Türkiye'de Tohumluk Sektörü ve Ayçiçeği Üreticilerinin Tohumluk Satın alma Davranışlarının Analizi: Trakya Bölgesi Örneği. XII. Ulusal Tarım Ekonomisi Kongresi. Süleyman Demirel Üniversitesi, Isparta,79-88.

Hazneci K, Ceylan V (2016) Buğday Tohumluğu Üretiminde Fiyat Değişkenliğinin İşletme Organizasyonuna Etkisi. XII. Ulusal Tarım Ekonomisi Kongresi. Süleyman Demirel Üniversitesi, Isparta, 69-78.

Kang G, Cai F, Zhang S (2015) Empirical Research on Factors that Influence the Behavior Decision of Repeated Seed Purchase for Farmers - Field investigation based on 519 vegetable farmers in Wuhan City SHS Web of Conferences 17.

Miran B (2010) Temel İstatistik. ISBN:975-93088-0-0. s.142. İzmir.
Öztürk F (2010) Isparta ilinde Kiraz İşletmelerinde Yeniliklerin Benimsenme ve Etki Değerlemesi. Yüksek Lisans Tezi, Selçuk Üniversitesi, Fen Bilimleri Enstitüsü

Usal G (1996) Adana İlinde Bitkisel Tohum Üretimi Yapan Firmaların Üretim Dağıtım Yapısı, Sorunları ve Çözüm Önerileri. Yüksek Lisans Tezi, Çukurova Üniversitesi, Fen Bilimleri Enstitüsü

Sav O (2014) Türkiye'de Sebze Tohumu Dış Ticaretine Yönelik İzlenen Politikaların Etkilerinin SWOT ve Sor Analizi İle İncelenmesi: Antalya illi Örneği. Yüksek Lisans Tezi, Akdeniz Üniversitesi, Fen Bilimleri Enstitüsü.

TSÜAB (2016) Tohum sanayicileri alt birliği tohum istatistikleri. Web sayfası: http://www.tsuab.org.tr. (Erişim tarihi: 10 Aralık 2016).

TOBAi (2016) T.C. Gıda Tarım Hayvancılık Bakanlığı Antalya Tarım îl Müdürlüğü örtüaltı işletme sayısı istatistikleri.

TÜiK (2019) Türkiye İstatistik Kurumu, örtüaltı ekim ve üretim istatistikleri. Web sayfası: http://www tuik.gov.tr. (Erişim tarihi: 11 Ekim 2019).

Worldseed (2016) Dünya tohum birliği tohum istatistikleri, web sayfası: http://www.worldseed.org/isf/seed statistics.html (Erişim tarihi: 11 Ekim 2016).

Yağdı K, Yılmaz K, Sezer N, Aydemir T, Bağcı SA (2010) Türkiye'de Tarla Bitkileri Tohumluk Üretimi ve Kullanımı ile Tohumculuk Sisteminin Genel Değerlendirilmesi. Ziraat Mühendisliği VII. Teknik Kongresi. Ankara, 861-875.

Yılmaz H (2014) An Analysis on Factors Influencing Government Supported Bumble Bees Use as Pollinators by Greenhouse Producers' In the Mediterranean Coastal Region of Turkey. Acta Sci. Pol., Hortorum Cultus 13(6), 59-70. 